\title{
The efficacy of intravenous aminocaproic acid in primary total hip and knee arthroplasty: a meta-analysis
}

\author{
Yong-jiang Li', Bi-sheng Xu, Sun-peng Bai, Xiao-jun Guo and Xiang-yuan Yan
}

\begin{abstract}
Background: We conducted a meta-analysis from randomized controlled trials (RCTs) and non-RCTs to assess the efficacy of aminocaproic acid in cases of primary total hip arthroplasty (THA) or total knee arthroplasty (TKA).

Methods: Potentially relevant academic articles were identified from the Cochrane Library, MEDLINE (1966-2017 October 31), PubMed (1966-2017 October 31), EMBASE (1980-2017 October 31), and ScienceDirect (1985-2017 October 31). Secondary sources were identified from the references of the included literature. The pooled data were analyzed using RevMan 5.1.

Results: Three RCTs and four non-RCTs met the inclusion criteria. There were significant differences in total blood loss (mean difference $(M D)=-495.80,95 \% \mathrm{Cl}-837.29$ to $-154.32, P=0.004$ ), drainage volume $(M D=-249.43$, $95 \% \mathrm{Cl}-286.78$ to $-212.08, P<0.00001)$, postoperative hemoglobin level $(\mathrm{MD}=0.90,95 \% \mathrm{Cl} 0.78$ to $1.02, P<0.00001)$, hemoglobin reduction ( $\mathrm{MD}=-0.75,95 \% \mathrm{Cl}-0.93$ to $-0.57, P<0.00001$ ), transfusion rates (risk difference $(\mathrm{RD})=-0.17$, $95 \% \mathrm{Cl}-0.25$ to $-0.09, P<0.0001)$, average transfusion units $(\mathrm{MD}=-0.28,95 \% \mathrm{Cl}-0.48$ to $-0.09, P=0.004)$, and length of hospital stay ( $\mathrm{MD}=-0.33,95 \% \mathrm{Cl}-0.43$ to $-0.24, P<0.00001)$ between the two groups. No significant differences were found regarding deep vein thrombosis (DVT) $(\mathrm{RD}=-0.00,95 \% \mathrm{Cl}-0.01$ to $0.00, P=0.36)$ between the two groups.

Conclusions: The present meta-analysis indicated that the application of aminocaproic acid in THA or TKA decreases the total blood loss, drainage volume, transfusion rate, transfusion units per patient, and length of hospital stay and does not increase the risk of DVT.
\end{abstract}

Keywords: Aminocaproic acid, Arthroplasty, Blood loss, Transfusion, Meta-analysis

\section{Background}

Total hip arthroplasty (THA) and total knee arthroplasty (TKA) are common treatment for treating the patients suffering end-stage joint disease [1,2]. It is known that significant blood loss may lead to acute anemia following a THA, and blood transfusions are often required for patients suffering from acute anemia and carry their own risks, such as inducing infectious disease, hemolysis, and anaphylactic reactions and increasing the economic burden [3, 4]. Multiple strategies have been utilized to minimize the blood loss, such as blood salvage, normovolemic hemodilution, electrocautery, hypotensive anesthesia,

\footnotetext{
* Correspondence: 18696368115@163.com

Department of Orthopedics, Tianmen City No.1 People's Hospital, Tianmen 431700, Hubei Province, People's Republic of China
}

and hemostatic agents [5]. However, many patients still require blood transfusions.

Various studies have reported that aminocaproic acid reduces blood loss and allogenic blood transfusions in primary THA and TKA [6-12]. However, the results are not consistent. Moreover, some limitations exist in previous studies such as small sample size, inconclusive results, and inaccurate evaluations. Therefore, we conducted a large sample meta-analysis to evaluate the efficacy of aminocaproic acid in primary THA and TKA from randomized controlled trials (RCTs) and non-RCTs.

\section{Methods}

\section{Search strategy}

Electronic databases were searched, including Cochrane Library, MEDLINE (1966-2017 October 31), PubMed

(c) The Author(s). 2018 Open Access This article is distributed under the terms of the Creative Commons Attribution 4.0 International License (http://creativecommons.org/licenses/by/4.0/), which permits unrestricted use, distribution, and reproduction in any medium, provided you give appropriate credit to the original author(s) and the source, provide a link to the Creative Commons license, and indicate if changes were made. The Creative Commons Public Domain Dedication waiver (http://creativecommons.org/publicdomain/zero/1.0/) applies to the data made available in this article, unless otherwise stated. 
(1966-2017 October 31), EMBASE (1980-2017 October 31), and ScienceDirect (1985-2017 October 31). We then manually searched the reference lists of all included studies, relevant books, review articles, and meeting proceedings to identify trials that might have been missed in the electronic search. The search process was conducted as follows in Fig. 1. The key words "aminocaproic acid" and "replacement OR arthroplasty" were used in combination with the Boolean operators AND or. We made no restrictions on the language of the publication. This study is a meta-analysis and did not need approval from the ethics committee or institutional review board.

\section{Inclusion criteria}

Studies were considered eligible for inclusion if they met the following criteria: (1) patients undergoing a primary THA or TKA; (2) the intervention used aminocaproic acid and studies contained a control group with placebo or null; (3) the outcomes included blood loss, operative time, blood transfusion rate, blood transfusion unit, perioperative outcomes, and complications; and (4) the study was a published or unpublished comparative trial (RCTs or non-RCTs).

\section{Exclusive criteria}

We excluded articles that were (1) studies without controlled groups, (2) articles without available fulltext versions, and (3) no available outcomes data.

\section{Selection criteria}

Two reviewers independently screened the titles and abstracts for eligibility criteria. Subsequently, the full text of the studies that potentially met the inclusion criteria were read, and the literature was reviewed to determine final inclusion. Disagreement was resolved by consulting a third reviewer.

\section{Quality assessment}

According to whether the study is a randomized or non-randomized trial, the methodological Index for

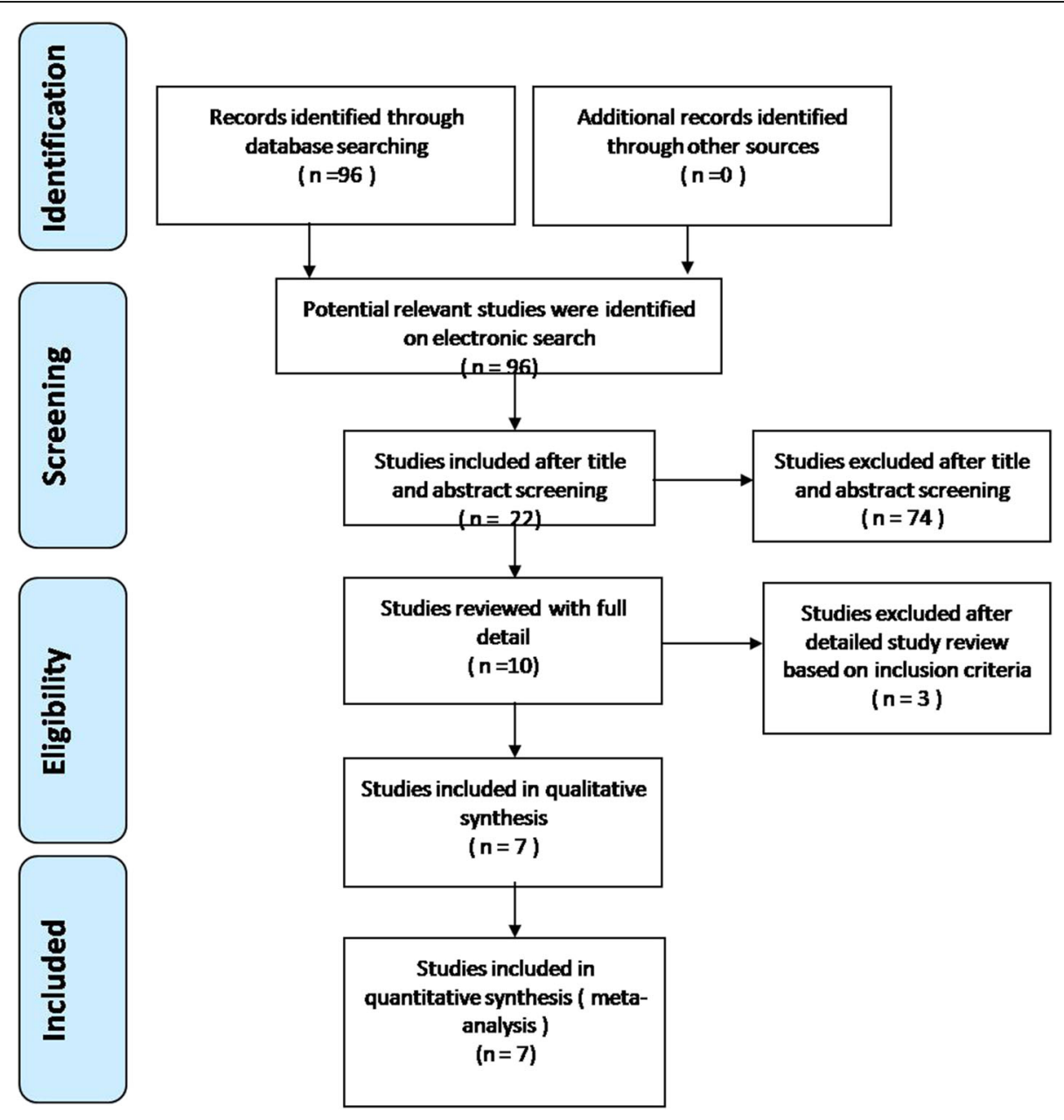

Fig. 1 Flow chart of the study selection and inclusion process 


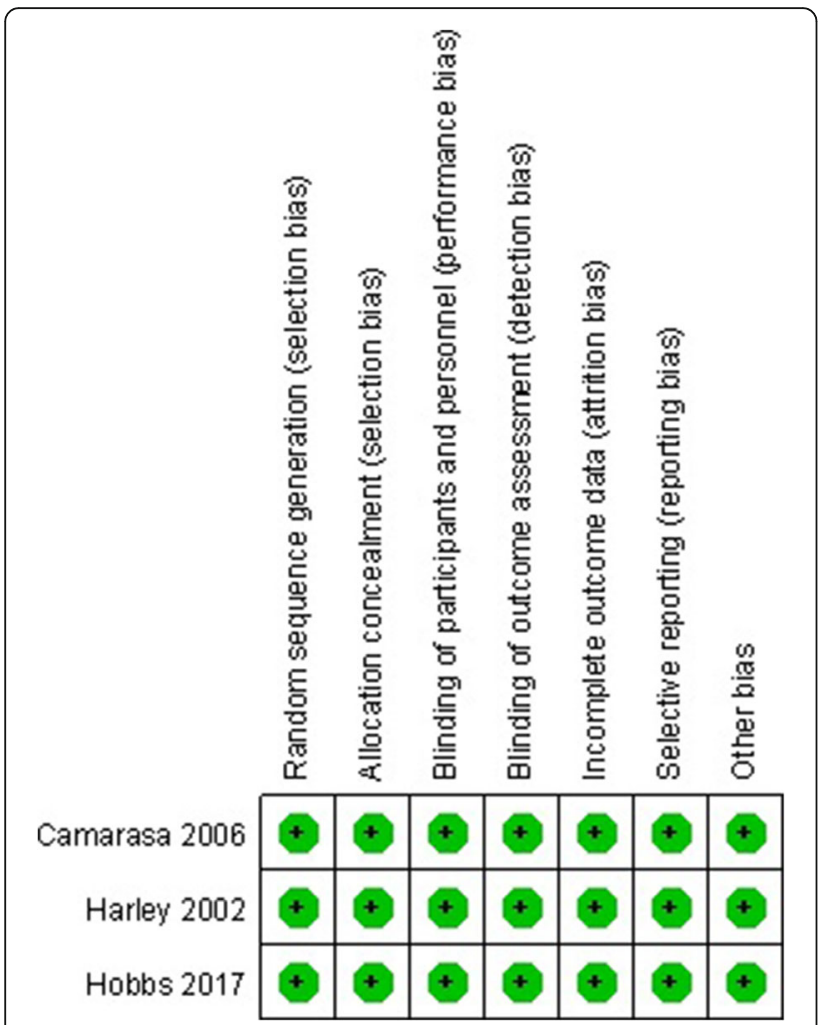

Fig. 2 The summary of bias risk of randomized controlled trials

Non-randomized Studies (MINORS) form was used to assess retrospective controlled trials [13]. Quality assessment for RCT was conducted according to a modification of the generic evaluation tool used by the Cochrane Bone, Joint and Muscle Trauma Group [14]. Disagreements were resolved by consensus or consultation with the senior reviewer.

\section{Data extraction}

Two researchers independently extracted the data from the included literature. The corresponding author was consulted for details in the case of incomplete data. The following information was extracted: first author name, year of publication, intervening measures, comparable baseline, sample size, and outcome measures. We contacted the authors of the studies for further information. Other relevant parameters were also extracted from individual studies.

\section{Data analysis and statistical methods}

Pooling of data was analyzed by RevMan 5.1 (The Cochrane Collaboration, Oxford, UK). Heterogeneity was estimated depending on the value of $P$ and $I^{2}$ using the standard chi-square test. When $I^{2}>50 \%, P<0.1$ was considered to be significant heterogeneity. Therefore, a random effects model was applied for data analysis. A fixed effects model was used when no significant heterogeneity was found. Subgroup analysis was performed to investigate sources in the case of significant heterogeneity. Mean difference (MD) and 95\% confidence interval (CI) were presented for continuous outcomes. Risk difference (RD) and $95 \%$ CIs were calculated for dichotomous data.

\section{Results}

\section{Search results}

A total of 96 studies were identified as potentially relevant literature reports. No additional studies were obtained after the reference review. Seventyfour studies were excluded after title and abstract screening, 22 studies reviewed with full detail, and 15 of studies excluded after detailed study review based on inclusion

Table 1 Quality assessment for non-randomized trials

\begin{tabular}{lllll}
\hline Quality assessment for non-randomized trials & Churchill et al. 2016 (THA) & Churchill et al. 2016 (TKA) & Churchill et al. 2017 Hobbs et al. 2017 \\
\hline A clearly stated aim & 2 & 2 & 2 & 2 \\
Inclusion of consecutive patients & 2 & 2 & 2 & 2 \\
Prospective data collection & 0 & 0 & 0 & 0 \\
Endpoints appropriate to the aim of the study & 2 & 2 & 2 & 2 \\
Unbiased assessment of the study endpoint & 2 & 2 & 2 & 2 \\
A follow-up period appropriate to the aims of study & 2 & 2 & 2 & 2 \\
Less than 5\% loss to follow-up & 2 & 2 & 0 & 2 \\
Prospective calculation of the sample size & 0 & 0 & 2 & 2 \\
An adequate control group & 2 & 2 & 2 & 2 \\
Contemporary groups & 2 & 2 & 2 & 2 \\
Baseline equivalence of groups & 2 & 2 & 2 & 2 \\
Adequate statistical analyses & 2 & 20 & 2 \\
Total score & 20 & 2 & 2
\end{tabular}


Table 2 Characteristics of included studies

\begin{tabular}{|c|c|c|c|c|c|c|c|}
\hline Study & Operation & $\begin{array}{l}\text { Cases } \\
\text { (A/C) }\end{array}$ & $\begin{array}{l}\text { Mean age } \\
(\mathrm{A} / \mathrm{C})\end{array}$ & $\begin{array}{l}\text { Gender } \\
(F)\end{array}$ & Dosage & $\begin{array}{l}\text { Prophylactic } \\
\text { anticoagulant }\end{array}$ & Transfusion trigger \\
\hline $\begin{array}{l}\text { Camarasa } \\
\text { et al. } 2006\end{array}$ & TKA & $32 / 60$ & $73 / 72$ & $28 / 48$ & $\begin{array}{l}100 \mathrm{mg} / \mathrm{kg} \text { administered intravenously in } \\
30 \mathrm{~min} \text { (before tourniquet release) }+3 \mathrm{~g} \text { for } \\
3 \mathrm{~h} \text { following first dose }\end{array}$ & LMWH & $\begin{array}{l}\mathrm{Hb}<8 \mathrm{~g} / \mathrm{dl} \text { or } 10 \mathrm{~g} / \mathrm{dl} \\
\text { with clinical symptoms }\end{array}$ \\
\hline $\begin{array}{l}\text { Churchill } \\
\text { et al. } 2017\end{array}$ & TKA & $820 / 1492$ & 63.9/63.9 & $527 / 956$ & $\begin{array}{l}5 \mathrm{~g}(\mathrm{BW}<50 \mathrm{~kg}) ; 10 \mathrm{~g}(\mathrm{BW}>50 \mathrm{~kg}) \\
\text { administered intravenously near the time } \\
\text { of tourniquet release }\end{array}$ & $\begin{array}{l}\text { Surgeon's } \\
\text { discretion }\end{array}$ & NS \\
\hline $\begin{array}{l}\text { Churchill et al. } \\
2016 \text { (THA) }\end{array}$ & THA & $911 / 643$ & $65.1 / 65.4$ & $392 / 377$ & $\begin{array}{l}5 \mathrm{~g}(\mathrm{BW}<50 \mathrm{~kg}) ; 10 \mathrm{~g}(\mathrm{BW}>50 \mathrm{~kg}) \\
\text { administered intravenously near the time } \\
\text { of incision }\end{array}$ & $\begin{array}{l}\text { Surgeon's } \\
\text { discretion }\end{array}$ & Surgeon's discretion \\
\hline $\begin{array}{l}\text { Churchill et al. } \\
2016 \text { (TKA) }\end{array}$ & TKA & $25 / 25$ & $65.2 / 66.6$ & $21 / 15$ & $\begin{array}{l}10 \mathrm{~g} \text { administered intravenously over } 10 \mathrm{~min} \\
\text { and was completely infused before } \\
\text { tourniquet deflation }\end{array}$ & Warfarin & $\begin{array}{l}\mathrm{Hb}<7 \mathrm{~g} / \mathrm{dl} \text { or } 9 \mathrm{~g} / \mathrm{dl} \\
\text { with clinical symptoms }\end{array}$ \\
\hline $\begin{array}{l}\text { Harley et al. } \\
2002\end{array}$ & THA & $26 / 29$ & $69 / 69$ & $16 / 18$ & $\begin{array}{l}150 \mathrm{mg} / \mathrm{kg} \text { administered intravenously over } \\
20 \mathrm{~min} \text { on the patient's arrival in the operating } \\
\mathrm{room}+12.5 \mathrm{mg} / \mathrm{kg} / \mathrm{h} \text { for an additional } 5 \mathrm{~h}\end{array}$ & Heparin & $\begin{array}{l}\mathrm{Hb}<80 \mathrm{~g} / \mathrm{L} \text { or } \mathrm{HCT}<0.24 \\
\text { or patients having } \\
\text { anemia symptoms }\end{array}$ \\
\hline $\begin{array}{l}\text { Hobbs et al. } \\
2017\end{array}$ & $\begin{array}{l}\text { THA and } \\
\text { TKA }\end{array}$ & 184/185 & $62.1 / 63.1$ & $14 / 14$ & $\begin{array}{l}5 \mathrm{~g} \text { administered intravenously over } 20 \mathrm{~min} \\
\text { before incision }+5 \mathrm{~g} \text { again during closure }\end{array}$ & $\begin{array}{l}\text { Asprin, } \\
\text { LMWH }\end{array}$ & Surgeon's discretion \\
\hline $\begin{array}{l}\text { Ray et al. } \\
2005\end{array}$ & THA & $15 / 15$ & $72 / 69$ & NS & $\begin{array}{l}10 \mathrm{~g} \text { administered intravenously over } 30 \mathrm{~min} \\
\text { after the induction of anesthesia }+5 \mathrm{~g} \text { over } 3 \mathrm{~h}\end{array}$ & Aspirin & NS \\
\hline
\end{tabular}

THA total hip arthroplasty, TKA total knee arthroplasty, $A$ aminocaproic acid, $C$ control, $F$ female, BW body weight, NS not state, $M$ male, $L M W H$ low molecular weight heparin, $H C T$ hematocrit, $H b$ hemoglobin

criteria. Ultimately, three RCTs and four non-RCTs were eligible for data extraction and meta-analysis. The search process is shown in Fig. 1.

\section{Risk of bias assessment}

RCT quality was assessed based on the Cochrane Handbook for Systematic Review of Interventions (Fig. 2). The RCT stated clear inclusion and exclusion criteria. Included RCT performed adequate methodology of randomization, concealment of allocation, blinding, and intent-to-treatment analysis. No unclear bias was reported due to incomplete outcome data or selective outcomes. For the non-RCTs, the MINORS scores were 18-20 for the retrospectively controlled trials. The methodological quality assessment is illustrated in Table 1.

\section{Study characteristics}

Demographic characteristics and details concerning the literature type of the included studies are summarized in
Table 2. Statistically similar baseline characteristics were observed between both groups.

\section{Outcomes of meta-analysis \\ Total blood loss}

Two of the included articles reported the outcomes for total blood loss $[10,12]$. There was significant heterogeneity $\left(\chi^{2}=4.00, \mathrm{df}=1, I^{2}=75 \%, P=0.05\right)$; as a result, a random model was applied. The pooled results demonstrated the total blood loss in the aminocaproic acid group was significantly lower than that in the control group $(\mathrm{MD}=-495.80,95 \% \mathrm{CI}-837.29$ to -154 . 32, $P=0.004$; Fig. 3).

\section{Drainage volume}

Drainage volume was reported in four included studies $[8,10-12]$. No significant heterogeneity was found, a fixed model was applied $\left(\chi^{2}=3.34, \mathrm{df}=3, I^{2}=10 \%, P=0\right.$. 34). The differences between the two groups was statistically significant $(\mathrm{MD}=-249.43,95 \%$ CI -286.78 to $-212.08, P<0.00001$; Fig. 4$)$.

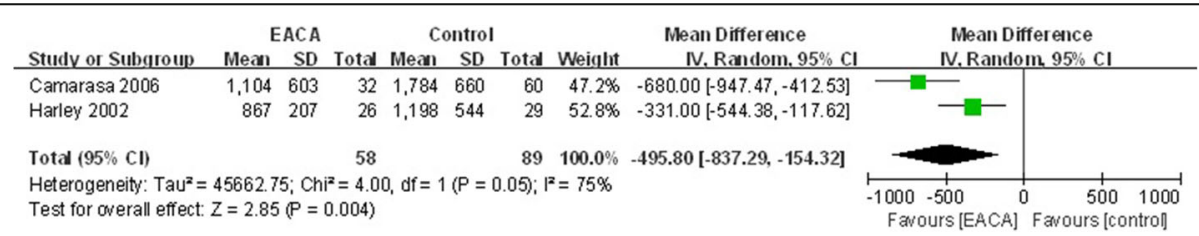

Fig. 3 Forest plot of total blood loss 


\begin{tabular}{|c|c|c|c|c|c|c|c|c|c|c|}
\hline & Studv or Subgroup & \multicolumn{2}{|c|}{ EACA } & \multicolumn{3}{|r|}{ Control } & & $\begin{array}{l}\text { Mean Difference } \\
\text { IV. Fixed. } 95 \% \mathrm{Cl}\end{array}$ & $\begin{array}{l}\text { Mean Difference } \\
\text { IV. Fixed. } 95 \% \mathrm{Cl}\end{array}$ \\
\hline & Camarasa 2006 & 810 & 512 & 32 & 1,270 & 624 & 60 & $2.5 \%$ & $-460.00[-697.48,-222.52]$ & \\
\hline & Churchill 2016(TKA) & 155 & 80 & 25 & 410.9 & 258.75 & 25 & $12.4 \%$ & $-255.90[-362.07,-149.73]$ & 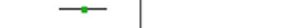 \\
\hline & Harley 2002 & 315 & 207 & 26 & 591 & 374 & 29 & $5.6 \%$ & $-276.00[-433.67,-118.33]$ & - \\
\hline & Ray 2005 & 210 & 35 & 15 & 450 & 75 & 15 & $79.5 \%$ & $-240.00[-281.88,-198.12]$ & $\square$ \\
\hline & Total $(95 \% \mathrm{Cl})$ & & & 98 & & & 129 & $100.0 \%$ & $-249.43[-286.78,-212.08]$ & $\bullet$ \\
\hline & $\begin{array}{l}\text { Heterogeneity: } \mathrm{Chi}^{2}=3 \\
\text { Test for overall effect: } Z\end{array}$ & $\begin{array}{l}34, d f= \\
=13.09\end{array}$ & $\begin{array}{l}=3(P \\
9(P<\end{array}$ & $\begin{array}{l}=0.34) \\
0.0000\end{array}$ & $\begin{array}{l}1^{2}=10 \\
\text { i1) }\end{array}$ & & & & & 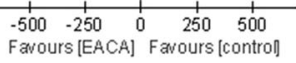 \\
\hline
\end{tabular}

\section{Postoperative hemoglobin level}

Three included studies reported postoperative hemoglobin level $[6,8,9]$. There was no significant heterogeneity $\left(\chi^{2}=0.17, \mathrm{df}=2, I^{2}=0 \%, P=0.92\right)$; as a result, a fixed model was applied. The pooled results demonstrated the postoperative hemoglobin level in the aminocaproic acid group was significantly higher than in the control group (MD $=0.90,95 \% \mathrm{CI} 0.78$ to $1.02, P<0$. 00001; Fig. 5).

\section{Hemoglobin reduction}

Hemoglobin reduction was reported in two included studies $[6,10]$. No significant heterogeneity was found, a fixed model was applied $\left(\chi^{2}=1.38, \mathrm{df}=1, I^{2}=27 \%, P=0.24\right)$. The differences between the two groups was statistically significant $(\mathrm{MD}=-0.75,95 \%$ CI -0.93 to $-0.57, P<0.00001$; Fig. 6$)$.

\section{Blood transfusion rate}

The blood transfusion rate was reported in seven included studies [6-12]. A random model was employed, which significant heterogeneity was found $\left(\chi^{2}=52.02\right.$, $\left.\mathrm{df}=6, I^{2}=88 \%, P<0.00001\right)$. The difference between the two groups in regard to the blood transfusion rate was statistically significant $(\mathrm{RD}=-0.17,95 \% \mathrm{CI}$ -0.25 to $-0.09, P<0.0001$; Fig. 7 ).

A subgroup analysis was performed for the blood transfusion rate, showing that this positive effect persisted regardless of the delivered dosage, whether the patient had received TKA or THA, and whether a transfusion protocol existed (Table 3).

\section{Transfusion units per patient}

Three included studies reported the outcome of the transfusion units per patient $[7,9,10]$. The random model was employed according to a significant heterogeneity $\left(X^{2}=26.32, \mathrm{df}=2, I^{2}=92 \%, P<0.00001\right)$. There were statistically significant differences between the two groups $(\mathrm{MD}=-0.28,95 \% \mathrm{CI}-0.48$ to -0.09 , $P=0.004$; Fig. 8).

\section{Deep vein thrombosis (DVT)}

The incidence of DVT had been reported in six studies $[6,7,9-12]$. The low significant heterogeneity was found, a fixed model was applied $\left(\chi^{2}=1.17, \mathrm{df}=5\right.$, $\left.I^{2}=0 \%, P=0.95\right)$. No significant differences between the groups were found ( $\mathrm{RD}=-0.00,95 \% \mathrm{CI}-0.01$ to $0.00, P=0.36$; Fig. 9 ).

\section{Length of hospital stay}

Two studies reported the length of hospital stay [7, 9]. There was significant heterogeneity shown between the pooled results; therefore, a random model was applied $\left(X^{2}=25.91, \mathrm{df}=1, I^{2}=96 \%, P<0.00001\right)$. There was a significant difference of length of hospital stay between the groups $(\mathrm{MD}=-0.33,95 \% \mathrm{CI}-0.43$ to $-0.24, P<0.00001$; Fig. 10).

\section{Discussion}

The most important results of the present meta-analysis were that the application of aminocaproic acid during a THA and TKA decreased total blood loss, drainage volume, transfusion rate, transfusion units per patient, and length of hospital stay and does not increase the risk of DVT. Moreover, the length of hospital stay was

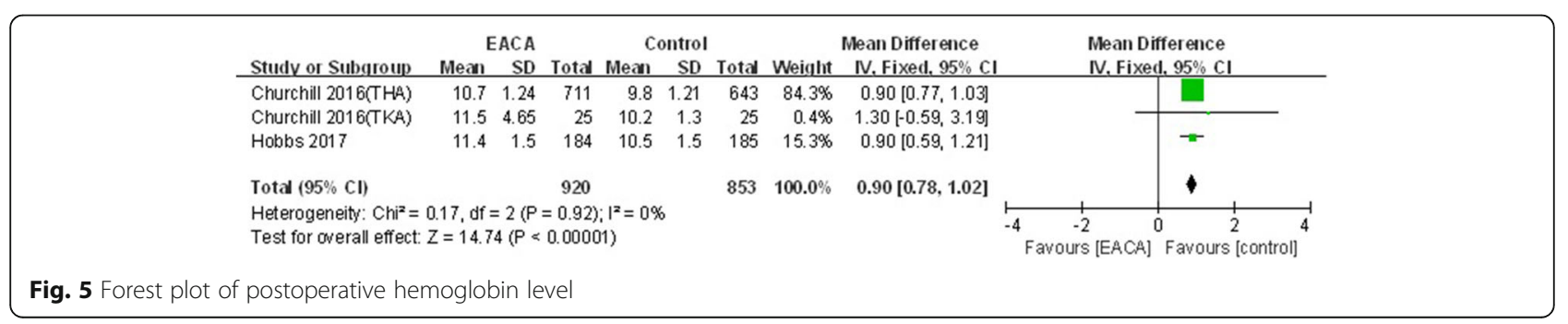




\begin{tabular}{|c|c|c|c|c|c|c|c|c|c|}
\hline Studv or Subgroup & \multicolumn{2}{|c|}{ EACA } & \multicolumn{4}{|c|}{ Control } & \multicolumn{2}{|c|}{$\begin{array}{lc} & \text { Mean Difference } \\
\text { Weight } & \text { IV. Fixed. } 95 \% \mathrm{Cl} \\
\end{array}$} & $\begin{array}{l}\text { Mean Difference } \\
\text { IV. Fixed, } 95 \% \mathrm{CI}\end{array}$ \\
\hline Camarasa 2006 & 2.4 & 1 & 32 & 3.4 & 1.2 & 60 & $15.4 \%$ & $-1.00[-1.46,-0.54]$ & - \\
\hline Hobbs 2017 & 2.7 & 0.8 & 184 & 3.4 & 1.1 & 185 & $84.6 \%$ & $-0.70[-0.90,-0.50]$ & \\
\hline Total $(95 \% \mathrm{Cl})$ & & & 216 & & & 245 & $100.0 \%$ & $-0.75[-0.93,-0.57]$ & \\
\hline $\begin{array}{l}\text { Heterogeneity: } \mathrm{Chi}^{2}= \\
\text { Test for overall effect: }\end{array}$ & $\begin{array}{l}1.38, d f= \\
Z=8.10\end{array}$ & $=1(\mathrm{P}$ & $\begin{array}{l}=0.24 \\
0.0000\end{array}$ & 1); $\left.\right|^{2}=2$ & $27 \%$ & & & & $\begin{array}{ccccc}1 & 1 & 1 & 1 & 1 \\
-1 & -0.5 & 0 & 0.5 & 1 \\
\text { Favours [EACA] } & \text { Favours [control] }\end{array}$ \\
\hline
\end{tabular}

shortened when aminocaproic acid was administered intravenously.

Aminocaproic acid, an antifibrinolytic drug, competitively block the lysine-binding site of plasminogen and has been used to reduce blood loss in surgery for many years [15]. The effectiveness of aminocaproic acid for decreasing perioperative blood loss during THA and TKA is widely reported. Present meta-analysis indicated that the intravenous application of aminocaproic acid could significantly decrease total blood loss and drainage volume. These results are similar to those of RCTs [10-12].

The indications for blood transfusion were based on hemoglobin levels and clinical symptoms of anemia [16]. Several studies have demonstrated that aminocaproic acid could reduce postoperative $\mathrm{Hb}$ reduction $[6,10]$. Our meta-analysis was consistent with these results. Pooled result also showed that postoperative hemoglobin level in the aminocaproic acid group was significantly higher than that in the control group. Although transfusion trigger varied from included studies, present meta-analysis indicates that the application of aminocaproic acid significantly decrease the blood transfusion rate and the average transfusion units. An RCT reported by Ray et al. [11] showed that aminocaproic acid does not reduce transfusion requirements. Their studies did not report the transfusion trigger.
Theoretically, antifibrinolytic agents may increase the risk of thrombotic events [17]. DVT is a common complication in orthopedic surgery, especially in arthroplasty, and may progress to pulmonary embolism and even death $[18,19]$. All included studies reported the use of an anticoagulant therapy after surgery. The meta-analysis showed that the use of aminocaproic acid did not increase the risk of DVT, which was $0.55 \%$ with the aminocaproic acid and 0 . $83 \%$ in the controls.

Several potential limitations should be noted. (1) Only seven studies were included, all of which had a relatively small sample size; (2) methodological weaknesses exist in all included studies, and some outcome parameters were not fully described so that we failed to perform a meta-analysis; and (3) subgroup analysis was not performed because of the limited number of included studies, and we could not determine the source of heterogeneity.

\section{Conclusions}

The present meta-analysis indicated that the application of aminocaproic acid in THA and TKA decreases the total blood loss, drainage volume, transfusion rate, transfusion units per patient, and length of hospital stay and does not increase the risk of DVT or other complications. 
Table 3 Subgroup analysis of blood transfusion rate

\begin{tabular}{lllllll}
\hline Outcome of subgroup & Studies & \multicolumn{3}{l}{ Effect estimate } & & \\
\cline { 2 - 6 } & & $X^{2}$ & $P^{2}(\%)$ & $\mathrm{RD}$ & $95 \% \mathrm{Cl}$ & $P$ value \\
\hline TKA & 3 & 13.34 & 88 & -0.22 & {$[-0.42,-0.02]$} & 0.03 \\
THA & 3 & 3.20 & 38 & -0.17 & {$[-0.21,-0.13]$} & 0.00001 \\
Transfusion trigger & 3 & 4.47 & 57 & -0.23 & {$[-0.35,-0.12]$} & 0.0001 \\
Continuous application & 4 & 4.88 & 39 & -0.20 & {$[-0.26,-0.14]$} & 0.00001 \\
\hline
\end{tabular}

TKA total knee arthroplasty, THA total hip arthroplasty, $\mathrm{Cl}$ confidence interval, $M D$ mean difference

\begin{tabular}{|c|c|c|c|c|c|c|c|c|c|}
\hline \multirow[b]{2}{*}{ Studv or Subgroup } & \multicolumn{2}{|c|}{ EACA } & \multicolumn{4}{|c|}{ Control } & \multirow{2}{*}{\multicolumn{2}{|c|}{$\begin{array}{ll} & \text { Mean Difference } \\
\text { Weight } & \text { IV. Random. } 95 \% \mathrm{Cl}\end{array}$}} & \multirow{2}{*}{$\begin{array}{l}\text { Mean Difference } \\
\text { IV.Random. } 95 \% \mathrm{Cl}\end{array}$} \\
\hline & Mean & SD & Total & Mean & SD & Total & & & \\
\hline Camarasa 2006 & 0.19 & 0.5 & 32 & 0.58 & 0.8 & 60 & $22.9 \%$ & $-0.39[-0.66,-0.12]$ & \\
\hline Churchill 2016 (THA) & 0.11 & 0.47 & 711 & 0.48 & 0.99 & 643 & $37.4 \%$ & $-0.37[-0.45,-0.29]$ & - 늠 \\
\hline Churchill 2017 & 0.05 & 0.33 & 820 & 0.19 & 0.6 & 1492 & $39.7 \%$ & $-0.14[-0.18,-0.10]$ & 믈 \\
\hline \multirow{2}{*}{\multicolumn{8}{|c|}{$\begin{array}{l}\text { Total }(95 \% \mathrm{Cl}) \quad 1563 \quad 2195 \quad 100.0 \% \\
\text { Heterogeneity: } \text { Tau }^{2}=0.02 ; \mathrm{Chi}^{2}=26.32, \mathrm{df}=2(\mathrm{P}<0.00001) ; \mathrm{I}^{2}=92 \% \\
\text { Test for overall effect: } \mathrm{Z}=2.86(\mathrm{P}=0.004)\end{array}$}} & $-0.28[-0.48,-0.09]$ & \\
\hline & & & & & & & & & 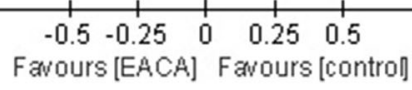 \\
\hline
\end{tabular}

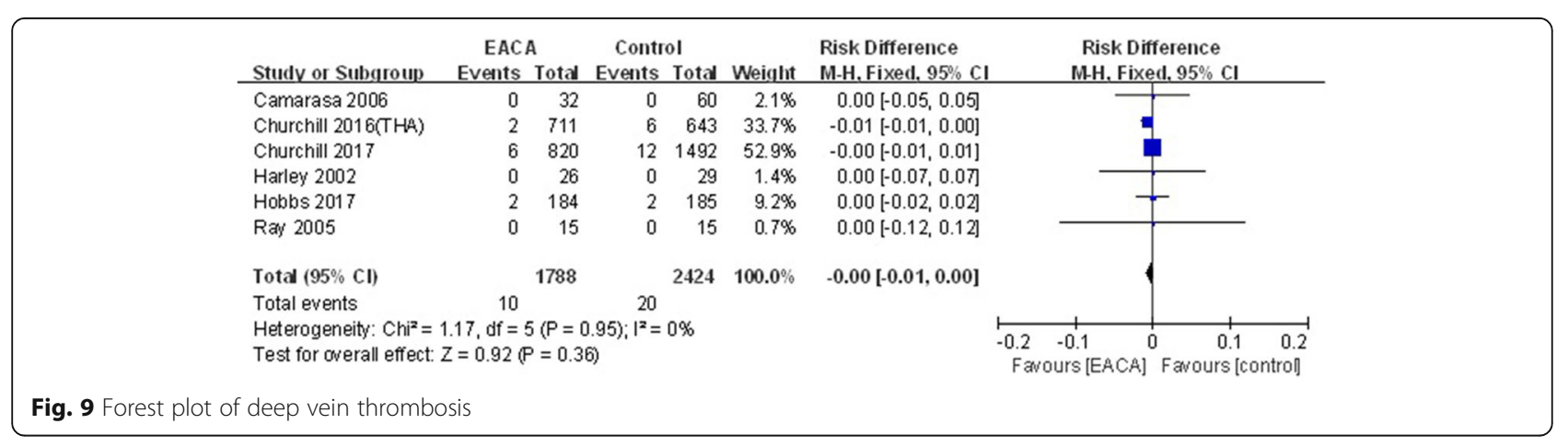

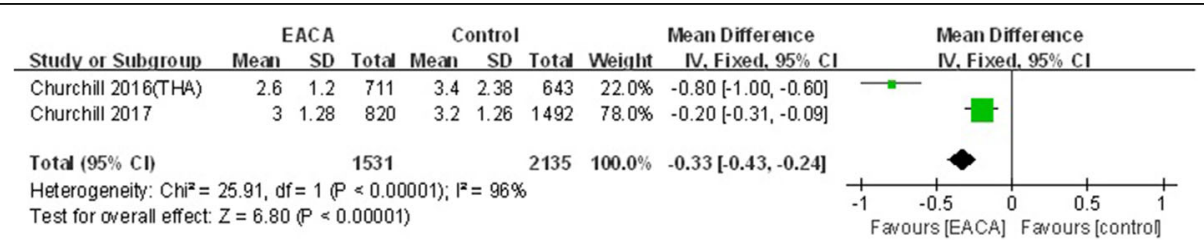

Fig. 10 Forest plot of length of hospital stay 


\section{Abbreviations}

Cl: Confidence interval; DVT: Deep vein thrombosis; MD: Mean difference; MINORS: Methodological Index for Non-randomized Studies; RCTs: Randomized controlled trials; RD: Risk difference; THA: Total hip arthroplasty; TKA: Total knee arthroplasty

\section{Acknowledgements}

We thank the authors of the included studies.

\section{Availability of data and materials}

As this paper is a meta-analysis, there are no patient data sets. The search strategy for the study selection supports the conclusion of the meta-analysis.

\section{Authors' contributions}

YJL and BSX conceived the study. YJL and SPB searched the literature and collected the data. YJL, XJG, BSX, and XYY performed the statistical analysis. YJL and BSX drafted the manuscript. XJG reviewed the manuscript. All authors have read and approved the final paper.

\section{Authors' information}

The author information can be found in the title page.

\section{Ethics approval and consent to participate}

Not applicable, this meta-analysis does not involve research on humans.

\section{Competing interests}

The authors declare that they have no competing interests.

\section{Publisher's Note}

Springer Nature remains neutral with regard to jurisdictional claims in published maps and institutional affiliations.

Received: 23 November 2017 Accepted: 3 April 2018

Published online: 17 April 2018

\section{References}

1. Finney A, Healey E, Jordan JL, Ryan S, Dziedzic KS. Multidisciplinary approaches to managing osteoarthritis in multiple joint sites: a systematic review. BMC Musculoskelet Disord. 2016;17:266.

2. Harato K, Kobayashi S, Kojima I, Sakurai A, Tanikawa H, Niki Y. Factors affecting one-leg standing time in patients with end-stage knee osteoarthritis and the age-related recovery process following total knee arthroplasty. J Orthop Surg Res. 2017;12(1):21.

3. Sizer SC, Cherian JJ, Elmallah RD, Pierce TP, Beaver WB, Mont MA. Predicting blood loss in total knee and hip arthroplasty. Orthop Clin North Am. 2015; 46(4):445-59.

4. Pedersen AB, Mehnert F, Overgaard S, Johnsen SP. Allogeneic blood transfusion and prognosis following total hip replacement: a populationbased follow up study. BMC Musculoskelet Disord. 2009;10:167.

5. Lerman DM, Rapp TB. Minimizing blood loss in orthopaedic surgery the role of antifibrinolytics. Bull Hosp Jt Dis (2013). 2015;73(2):83-9.

6. Hobbs JC, Welsby IJ, Green CL, Dhakal IB, Wellman SS. Epsilon aminocaproic acid to reduce blood loss and transfusion after total hip and Total knee arthroplasty. J Arthroplast. 2018;33(1):55-60.

7. Churchill JL, Puca KE, Meyer E, Carleton M, Anderson MJ. Comparing epsilon-aminocaproic acid and tranexamic acid in reducing postoperative transfusions in total knee arthroplasty. J Knee Surg. 2017;30(5):460-6.

8. Churchill JL, Toney VA, Truchan S, Anderson MJ. Using aminocaproic acid to reduce blood loss after primary unilateral total knee arthroplasty. Am J Orthop (Belle Mead NJ). 2016:45(5):E245-8.

9. Churchill JL, Puca KE, Meyer ES, Carleton MC, Truchan SL, Anderson MJ. Comparison of epsilon-aminocaproic acid and tranexamic acid in reducing postoperative transfusions in total hip arthroplasty. J Arthroplast. 2016; 31(12):2795-9. e2791

10. Camarasa MA, Olle G, Serra-Prat M, Martin A, Sanchez M, Ricos P, Perez A, Opisso L. Efficacy of aminocaproic, tranexamic acids in the control of bleeding during total knee replacement: a randomized clinical trial. Br J Anaesth. 2006;96(5):576-82.

11. Ray M, Hatcher S, Whitehouse SL, Crawford S, Crawford R. Aprotinin and epsilon aminocaproic acid are effective in reducing blood loss after primary total hip arthroplasty - a prospective randomized double-blind placebocontrolled study. J Thromb Haemost. 2005:3(7):1421-7.

12. Harley BJ, Beaupre LA, Jones CA, Cinats JG, Guenther CR. The effect of epsilon aminocaproic acid on blood loss in patients who undergo primary total hip replacement: a pilot study. Can J Surg. 2002;45(3):185-90.

13. Slim K, Nini E, Forestier D, Kwiatkowski F, Panis Y, Chipponi J. Methodological index for non-randomized studies (minors): development and validation of a new instrument. ANZ J Surg. 2003;73(9):712-6.

14. Handoll HH, Gillespie WJ, Gillespie LD, Madhok R. The Cochrane Collaboration: a leading role in producing reliable evidence to inform healthcare decisions in musculoskeletal trauma and disorders. Indian J Orthop. 2008;42(3):247-51.

15. Levy JH, Tanaka KA. Management of surgical hemostasis: systemic agents. Vascular. 2008;16(Suppl 1):S14-21.

16. Ponnusamy KE, Kim TJ, Khanuja HS. Perioperative blood transfusions in orthopaedic surgery. J Bone Joint Surg Am. 2014;96(21):1836-44.

17. Foreman PM, Chua M, Harrigan MR, Fisher WS 3rd, Tubbs RS, Shoja MM, Griessenauer CJ. Antifibrinolytic therapy in aneurysmal subarachnoid hemorrhage increases the risk for deep venous thrombosis: a case-control study. Clin Neurol Neurosurg. 2015;139:66-9.

18. Mitani G, Takagaki T, Hamahashi K, Serigano K, Nakamura Y, Sato M, Mochida J. Associations between venous thromboembolism onset, D-dimer, and soluble fibrin monomer complex after total knee arthroplasty. J Orthop Surg Res. 2015;10:172.

19. Zhang J, Chen Z, Zheng J, Breusch SJ, Tian J. Risk factors for venous thromboembolism after total hip and total knee arthroplasty: a metaanalysis. Arch Orthop Trauma Surg. 2015;135(6):759-72.

\section{Ready to submit your research? Choose BMC and benefit from:}

- fast, convenient online submission

- thorough peer review by experienced researchers in your field

- rapid publication on acceptance

- support for research data, including large and complex data types

- gold Open Access which fosters wider collaboration and increased citations

- maximum visibility for your research: over $100 \mathrm{M}$ website views per year

At BMC, research is always in progress.

Learn more biomedcentral.com/submissions 